\title{
Anatomy of the Velopharyngeal Valve
}

\section{(a)Ahmed El Sayed Gelaney and (b)Abeer Fareed Abd El-Naeem}

(a)Lecturer of phoniatrics . Faculty of Medicine. sohag university.

(b) Lecturer of human anatomy and embryology. Faculty of Medicine. sohag university.

\begin{abstract} dysfunction This valve is made up of the following structures:

Velum (also called soft palate)

Lateral pharyngeal walls - the side walls of the throat

Posterior pharyngeal wall - the back wall of the throat
\end{abstract}

Introduction: Understanding the normal anatomy and physiology of the velopharyngeal mechanism is the first step in providing appropriate diagnosis and treatment for children born with cleft lip and palate. The function of the velopharyngeal mechanism is to create a tight seal between the velum and pharyngeal walls to separate the oral and nasal cavities for various purposes, including speech.

Objective of the review: To study the anatomy of velopharyngeal valve and its

Summary: The velopharyngeal valve is very important for normal speech production.

Conclusion: Understanding the anatomy of velopharyngeal valve is important to know various types of dysfunction

Keywords: Velopharyngeal insufficiency, palate, pharynx, velum.

\section{Introduction}

Anatomy:The velopharyngeal valve is that valve separating the oropharynx and the nasopharynx. It is bounded anteriorly by the velum, laterally and posteriorly by the lateral and posterior pharyngeal walls(figure 1). The velum is a fibromuscular organ that is attached anteriorly to the hard palate, laterally to the lateral walls of the pharynx and palatal arches; posteriorly it extends into a free edge and in the midline is prolonged into the uvula (Hirshberg, 1986).

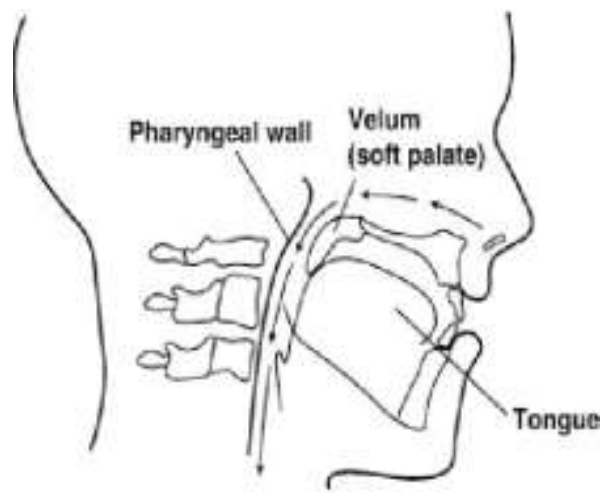

Figure 1.velopharyngeal valve. After Satoh et al.,2005

The palate comprises the rigid bony hard palate anteriorly and the mobile muscular soft plate (velum) posteriorly. The hard palate is a bony structure that separates the oral cavity from the nasal cavity. The outer portion of the hard palate is called the alveolar ridge. The hard palate is made up of fused bony segments that are 
separated by the incisive foramen (Kummer, 2014).

In some individuals, palatine torus (prominent longitudinal ridge on the oral surface of the hard palate in the area of the median suture line)(figure 2) can become bigger with age. This finding is a normal variation, rather than an abnormality most commonly seen in Caucasians of northern European descent, Native Americans, or Eskimos. It tends to occur more in the females than in the males (Garcia, et. al., 2010).

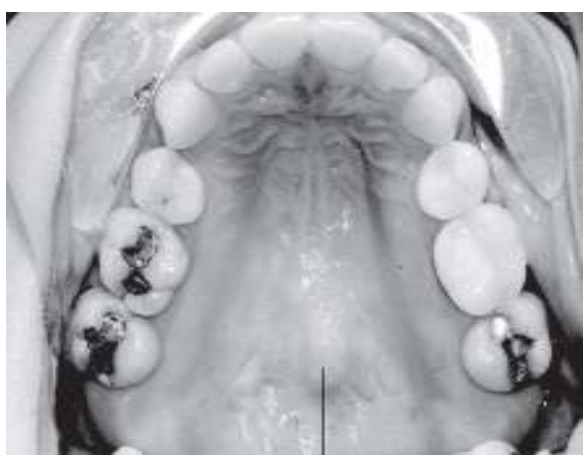

figure 2.palatine torus .After Garcia et al.,2010

\section{Velum}

The velum is attached to the posterior border of the hard palate and is held in place by its internal muscles .The velum has an oral surface and a nasal surface. The oral surface of the velum is covered by a mucous membrane that contains fine blood vessels. A thin white line, called the median palatine raphe, can be seen coursing down the midline of the velum on the oral surface. The nasal surface of the velum consists anteriorly of pseudostratified, ciliated columnar epithelium, and posteriorly of stratified, squamous epithelium in the area where the velum contacts the posterior pharyngeal wall during closure activities (Serrurier\& Badin, 2008).

The anterior portion of the velum has very few muscle fibers. Instead, it consists of the tensor tendon, glandular tissue, adipose tissue, and the palatine aponeurosis. The palatine aponeurosis consists of a sheet of fibrous connective tissue and fibers from the tensorvelipalatini tendon. It attaches to the posterior border of the hard palate and courses about $1 \mathrm{~cm}$ posteriorly through the velum. The palatine aponeurosis provides an anchoring point for the velopharyngeal muscles and adds stiffness to that portion of the velum (Hwang et al., 2011).

The uvula is a tear-drop shaped structure. It hangs freely from the posterior border of the velum. It is more vascular than the connecting velum. It consists of mucosa on the surface and connective, glandular, and adipose tissue underneath. However it is not a contributor to velopharyngeal function and has no known function (Kummer, 2005).

Muscles of the Velopharyngeal valve The velopharyngeal sphincter requires the coordinated action of several different muscles, all of which are paired, with one muscle of the pair on each side of the midline (Table )(Perry et al., 2011). 
SOHAG MEDICAL JOURNAL

Vol. 23 No.1 Jan 2019
Anatomy of the Velopharyngeal Valve

Abeer Fareed Abd El-Naeem.et al

\begin{tabular}{|c|c|c|c|c|}
\hline Muscle & Origin & Insertion & Innervation & Function \\
\hline $\begin{array}{l}\text { Tensor } \\
\text { Veli } \\
\text { Palatini }\end{array}$ & $\begin{array}{l}\text { Scafoid fossa of } \\
\text { sphenoid bone, fibrous } \\
\text { part } \\
\text { pharyngeotympanic tube } \\
\text { and spine of spheniod }\end{array}$ & $\begin{array}{l}\text { Palatine } \\
\text { aponeurosis }\end{array}$ & $\begin{array}{l}\text { Mandibular } \\
\text { nerve via the } \\
\text { branch to } \\
\text { medial } \\
\text { pterygoid } \\
\text { muscle }\end{array}$ & $\begin{array}{l}\text { Tenses the soft } \\
\text { palate. Opens the } \\
\text { pharyngeotympan } \\
\text { ic tube }\end{array}$ \\
\hline $\begin{array}{l}\text { Levator } \\
\text { Veli } \\
\text { Palatini }\end{array}$ & $\begin{array}{l}\text { Apex of the petrous } \\
\text { portion of the temporal } \\
\text { bone anterior to opening } \\
\text { for carotid canal }\end{array}$ & $\begin{array}{l}\text { Superior } \\
\text { surface of } \\
\text { Palatine } \\
\text { aponeurosis }\end{array}$ & $\begin{array}{l}\text { Vagus nerve } \\
\text { via pharyngeal } \\
\text { branch to } \\
\text { pharyngeal } \\
\text { plexus } \\
\end{array}$ & $\begin{array}{l}\text { Only musle to } \\
\text { elevate the soft } \\
\text { palate above } \\
\text { neutral position }\end{array}$ \\
\hline $\begin{array}{l}\text { Palato- } \\
\text { pharyngeus }\end{array}$ & $\begin{array}{ll}\text { Superior surface } & \text { of } \\
\text { Palatine aponeurosis } & \end{array}$ & $\begin{array}{l}\text { Pharyngeal } \\
\text { wall }\end{array}$ & $\begin{array}{l}\text { Vagus nerve } \\
\text { via pharyngeal } \\
\text { branch to } \\
\text { pharyngeal } \\
\text { plexus }\end{array}$ & $\begin{array}{l}\text { Depresses the soft } \\
\text { palate. Moves the } \\
\text { palatopharyngeal } \\
\text { arch toward } \\
\text { midline. Elevates } \\
\text { pharynx. }\end{array}$ \\
\hline $\begin{array}{l}\text { Palato- } \\
\text { glossus }\end{array}$ & $\begin{array}{l}\text { Inferior surface of } \\
\text { Palatine aponeurosis }\end{array}$ & $\begin{array}{l}\text { Lateral } \\
\text { margins of the } \\
\text { tongue }\end{array}$ & $\begin{array}{l}\text { Vagus nerve } \\
\text { via pharyngeal } \\
\text { branch to } \\
\text { pharyngeal } \\
\text { plexus }\end{array}$ & $\begin{array}{l}\text { Depresses the soft } \\
\text { palate. Moves the } \\
\text { palatoglossal arch } \\
\text { toward midline. } \\
\text { Elevates back of } \\
\text { the tongue. }\end{array}$ \\
\hline $\begin{array}{l}\text { Musculus } \\
\text { Uvulae }\end{array}$ & $\begin{array}{l}\text { Posterior nasal spine of } \\
\text { the hard palate }\end{array}$ & $\begin{array}{l}\text { Connective } \\
\text { tissue of the } \\
\text { uvula }\end{array}$ & $\begin{array}{l}\text { Vagus nerve } \\
\text { via pharyngeal } \\
\text { branch to } \\
\text { pharyngeal } \\
\text { plexus }\end{array}$ & $\begin{array}{l}\text { Elevates and } \\
\text { retracts uvula. } \\
\text { Thickens central } \\
\text { portion of the soft } \\
\text { palate. }\end{array}$ \\
\hline
\end{tabular}

Table : muscles of the palate (Drake et al., 2014).

Velopharyngeal Motor and Sensory Innervation:

Motor innervation for the muscles that contribute to velopharyngeal closure comes from the pharyngeal plexus .The pharyngeal plexus is a network of nerves that lies along the posterior wall of the pharynx and consists of the pharyngeal branches of the glossopharyngeal nerve (CN IX), the vagus nerve $(\mathrm{CN} \mathrm{X})$ through cranial part of accessory nerve and sympathetic thoracicplexus. (Kennedy \& Kuehn, 1989; Cassell\&Elkadi, 1995; Moon \& Kuehn, 1996). The palatoglossus muscle has also been found to receive innervation from the hypoglossal nerve (CN XII) (Cassell\&Elkadi, 1995). The tensor velipalatini, which does not contribute to velopharyngeal closure, receives motor innervations from the mandibular division of the trigeminal nerve $(\mathrm{CN}$ V). Sensory innervation of both the hard and soft palate is believed to derive from the greater and lesser palatine nerves, which arise from the maxillary division of the trigeminal nerve (CN V) (Perry, 2011).

Applied anatomy:Velopharyngeal dysfunction (VPD) is a general term. It is used to describe different disorders of the velopharyngeal valve. These include:

\section{Velopharyngeal Insufficiency}

It is usually caused by an abnormality of soft palate. Velopharyngeal insufficiency is common in children with cleft palate or a submucous (under the skin) cleft(Sullivan et al.,2011).

Velopharyngeal Incompetence 
It occurs due to paralysis of the velum due to injury to its nerve supply (Albert, 2012).

\section{VelopharyngealMislearning}

When the child makes sounds in the pharynx, rather than in the mouth. Because of this placement, the velopharyngeal valve is open and the air and sound go through the nose(Kummer, 2014).

Recommendations: More researches are needed to study the anatomy of velopharyngeal valve .

\section{References}

1. Albert S. Woo (2012): Velopharyngeal Dysfunction SeminPlast Surg. 2012 Nov; 26(4): 170-177.

2. Cassell, M. D., and Elkadi, H. (1995): Anatomy and physiology of the palate and velopharyngeal structures. In R. J. Shprintzen\& J. Bardach (Eds.), Cleft palate speech management: A multidisciplinary approach St. Louis, MO: Mosby :pp. 45-62.

3. Drake, R.L. Vogl, A.W. and Mitchell, A. (2014): Gray's Anatomy for Students. Elseveir/students consult $3^{\text {rd }}$ edch 8. Head and Neck: PP 863940.

4. Garcia-Garcia, A. S., MartinezGonzalez, J. M.,Gomez-Font, R., Soto-Rivadeneira, A., \&OviedoRoldan, L. (2010): Current status of the torus palatinus and torus mandibularis. Medicina Oral Patología Oral y CirugíaBucal, 15(2) :pp353360.

5. Hirschberg, J. (1986): Velopharyngeal insufficiency. Folia Phoniatrica, 38: pp221-276.

6. Hwang, K., Kim, D. J., Huan, F., Han, S. H., \&Hwang, S. W. (2011): Width of the levatoraponeurosis is broader than the tarsal plate. Journal of Craniofacial Surgery, 22(3):pp 10611063.

7. Kennedy, J. G., \& Kuehn, D. P. (1989):Neuroanatomy of speech. In D. P.Kuehn, M. L. Lemme,\&J.M. Baumgartner (Eds.), Neural bases of speech, hearing, and language Boston: College-Hill Press:(pp.111-145).
8. Kummer, A .W. (2005): Cleft palate and craniofatial anomalies: The effects on speech and resonance. Cincinnata, Ohio: WB Saunders:pp 401-424.

9. Kummer, A.W. (2014): Cleft palate and craniofatial anomalies: The effects on speech and resonance. The third edition. Cincinnata, Ohio.Cengage Learning.

10.Moon, J. B., \& Kuehn, D. P. (1996): Anatomy and physiology of normal and disordered velopharyngeal function for speech. National Center for Voice and Speech, 9 (April): pp 143-158.

11.Perry, J. L. (2011): Anatomy and physiology of the velopharyngeal mechanism. Seminars in Speech and Language, 32(2):pp 83-92.

12.Perry JL(2011): Anatomy and physiology of the velopharyngeal mechanism. Semin Speech Lang. 2011 May ;32(2): pp 83-92.

13.Perry, J. L., Kuehn, D. P., and Sutton, B. P. (2011): Morphology of the LevatorVeliPalatini Muscle Using Magnetic ResonanceImaging. Cleft Palate and CraniofacialJournal.

14.Satoh, K., Wada, T., Tachimura, T., \& Fukuda, J. (2005): Velar ascent and morphological factors affecting velopharyngeal function in patients with cleft palate and non cleft controls: A cephalometric study. International Journal of Oral and MaxillofacialSurgery, 34(2):pp 122126.

15.Serrurier, A., and Badin, P. (2008): A three dimensional articulatory model of the velum and nasopharyngeal wall based on MRI and CT data. Journal of the Acoustic Society of America, 123(4):pp 2335-2355.

16.Sullivan $S \quad R$, Vasudavan $S$, Marrinan $\mathbf{E} \mathbf{M}$, and Mulliken $\mathbf{J}$ B.(2011): Submucous cleft palate and velopharyngeal insufficiency: comparison of speech outcomes using three operative techniques by one surgeon. Cleft Palate Craniofac J. 2011;48(5):pp561-570. 